\title{
Mechanism and Suppression Method of Hydrogen Entry into Steel by Blasting
}

\author{
Makoto Kawamori ${ }^{1)^{*}}$, Fumio Yuse $^{1)}$, Yosuke Funita ${ }^{2)}$ and Hideyuki Ikegami $^{2)}$ \\ 1) Materials Research Laboratory, Technical Development Group, Kobe Steel, Ltd. \\ 2) Material Solutions Division, Kobelco Research Institute, Inc.
}

Abstract: The effect of blasting on hydrogen analysis was investigated with the aim of establishing a hydrogen analysis method for precisely measuring hydrogen that entered steel in a corrosive environment. The hydrogen existing states of the specimens blasted under various conditions were analyzed using thermal desorption analysis and the hydrogen visualization method by secondary ion mass spectrometry. The phenomenon of hydrogen entry into steel by blasting was demonstrated for the first time. It should be noted that the effect is remarkable in the case of a specimen with a large specific surface area, and the blasting becomes an inhibitory agent in the measurement of the hydrogen content in steel. The hydrogen source for increasing the hydrogen content due to blasting is mainly the water contained in the abrasive. The mechanism of increasing the hydrogen content in steel by blasting is that the fresh surface of the steel exposed by blasting reacts with the water in the abrasive, which results in the hydrogen generation and entry into steel. Additionally, the water in the abrasive remaining on the steel surface reacts with steel during the thermal desorption analysis to release hydrogen. To suppress the increase of hydrogen content by blasting, it is effective to use abrasive with low water content and to remove rust by repeating a short blasting time in order to suppress the temperature rise of the specimen.

Keywords: blasting; hydrogen embrittlement; hydrogen entry; hydrogen visualization; steel; atmospheric corrosion; thermal desorption analysis; secondary ion mass spectrometry.
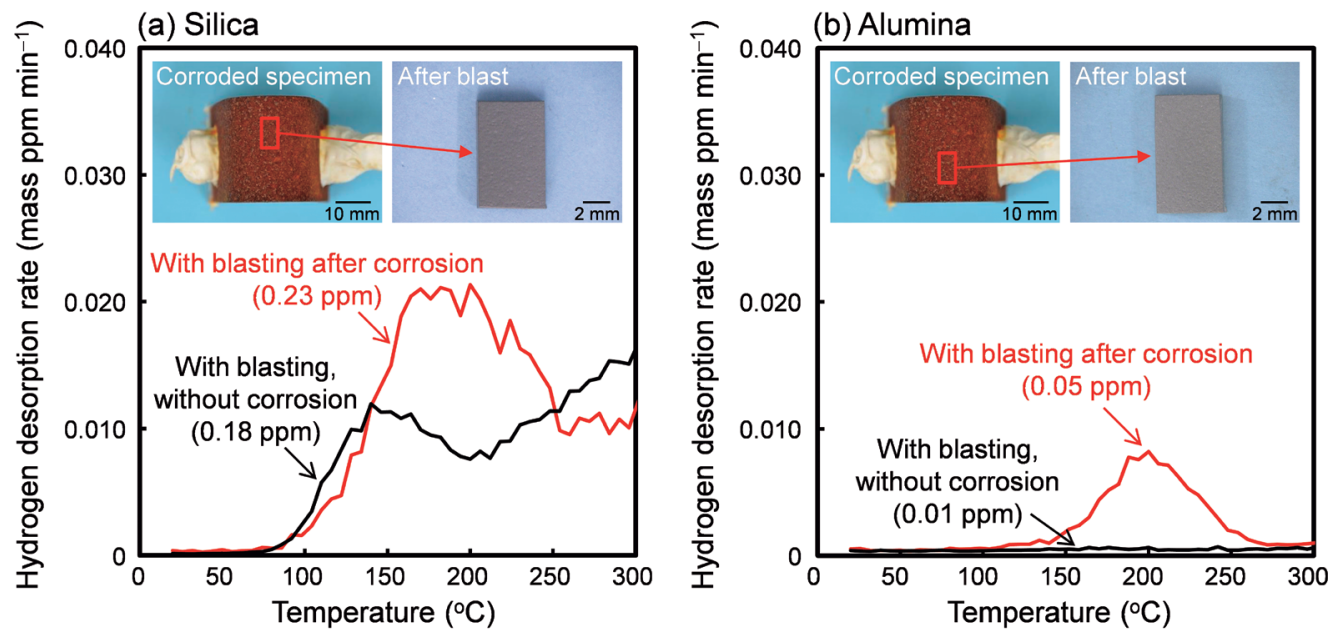

Received on Dec. 21, 2020 ; Accepted on Jan. 29, 2021 ; J-STAGE Advance published on Mar. 8, 2021

* Corresponding author. E-mail: kawamori.makoto@kobelco.com, Address: Kobe Steel, Ltd., 1-5-5 Takatsukadai Nishi-ku Kobe Hyogo 651-2271 


\title{
ブラスト処理による鋼への水素侵入の機構と抑制方法
}

\author{
河盛 誠 $^{1) *}$. 湯瀬 文雄 $^{1)} \cdot$ 藤田 陽介 ${ }^{2)} \cdot$ 池上 英之 ${ }^{2)}$
}

Mechanism and Suppression Method of Hydrogen Entry into Steel by Blasting

Makoto Kawamori, Fumio Yuse, Yosuke Fujita and Hideyuki Inegami

\section{1. 緒言}

環境負荷の低減に向けて, 自動車をはじめとする輸送機 器の $\mathrm{CO}_{2}$ 排出量削減は重要な課題であり, 使用される材料 の軽量化および高強度化は有効な手段の一つである。鋼は 他の材料と比較して高強度を得やすく, 安価, 加工しやす いなど多くの利点を有しているが, 高強度化に伴い水素脆 化感受性が高くなるため, 水素脆化の抑制が実用化に向け た最大の課題となる。水素脆化は材料, 環境, 応力の各因 子が組み合わさった特定の条件下で引き起こされる ${ }^{1,2)}$ 。水 素脆化の抑制を目的として，材料の観点からこれまで多く の検討が行われてきた。一例として, 粒界破壞の原因とさ れる不純物 $\mathrm{P}, \mathrm{S}$ の低減や, 粒界炭化物制御のための焼戻し 温度の高温化, Ti, Vなどの元素添加による結晶粒微細化な どが挙げられる ${ }^{3-6)}$ 。

高強度鋼の実用化を検討する上では, 実環境や負荷応力 を考慮した水素脆化評価法が必要不可欠となる。水素脆化 評価法として, 暴露試験 ${ }^{7,8)}$, ボルト用鋼材に関する JIS 原 案法 ${ }^{1)}$, 水素量を基準とした評価法 ${ }^{9-12)}$, 複合サイクル試 験による評価法 ${ }^{13)}$, 内在的因子による水素脆化感受性評価 法 $^{14)}$ などが検討されている。暴露試験は実際に近い応力状 態における実環境での試験であるが, 評価時間が長くなっ てしまう欠点を有している。そこでラボでの加速試験とし て JIS 原案法が提案されたが, 暴露試験結果と一致しない ことが報告されている ${ }^{1,10)}$ 。近年では, 水素量測定に基づく 方法が各種提案されている。例えばSuzuki らは昇温脱離分 析を用いて水素脆化が発生する限界の水素量が存在する ことを確かめ ${ }^{9)}$, Yamasaki and Takahashi は環境から侵入す る水素量との比較を行い, 水素脆化感受性を評価する方法 を提案している ${ }^{10)}$ 。しかしながら, 標準的な水素脆化評価 法は未だ確立されておらず, 水素脆化研究の課題の 1 つと なっている。暴露試験や水素量を基準とする評価法におい ては, 腐食環境下における鋼の侵入水素量を正確に評価す る必要がある。また, 実用化を検討する上で, 実環境下で の侵入水素量を把握することが理想的である。
大気暴露などの実環境下における侵入水素量はこれ までに報告されており, 腐食によって侵入する水素は $10^{-2}-10^{-1}$ mass ppmのオーダーであり比較的微量であ る ${ }^{15-18)}$ 。また, 強度の高い鋼では, 0.1 mass ppm以下の微量 な水素量でも水素脆化が引き起こされるため, 精緻な水素 量測定が求められる。近年の分析技術の高度化によって, 精緻な水素分析が可能となっており, 例えば昇温脱離分析 では $0.01 \mathrm{ppm}$ オーダーの定量的な水素量測定が可能であ る。しかし, 特に水素分析の前処理が水素量測定に与える 影響についてはほとんど報告されておらず, 検討の余地が 大きい。環境から侵入した水素量を正確に評価するために は, 水素量測定における阻害因子を把握し, 極力除去する ことが望ましい。水素量測定における代表的な阻害因子と して錆の影響が挙げられる。錆が付着した状態で昇温脱離 分析による水素量測定を行うと, 錆由来の水素が発生する ため, 鋼中水素量を過度に評価してしまう可能性があるこ とが報告されている ${ }^{19)}$ 。錆の除去には機械研磨が用いられ る他, 研磨を行いにくい形状を有する試験片にはブラスト 処理が使用されることが多い ${ }^{8,15,18)}$ 。しかしながら, 水素量 測定に及ぼすブラスト処理の影響を調査した報告例はな W。

そこで本研究では, 腐食環境で鋼に侵入した水素を精緻 に測定するための水素分析方法の確立を目的として, 水素 量測定に及ぼすブラスト処理の影響を調査した。そしてブ ラスト処理によって鋼に水素が侵入する現象を初めて明 らかにした。昇温脱離分析による水素量測定および二次イ オン質量分析 (Secondary Ion Mass Spectrometry (SIMS) ) に よる水素可視化手法を用いて, 各種条件でブラスト処理を 行った試験片の水素存在状態を解析し, 水素侵入の機構お よび抑制方法を調査した結果について報告する。

\section{2. 実験}

\section{$2 \cdot 1$ 供試材}

供試材には, Table 1 に記載の化学成分を有する板厚 1.6

2020年12月21日受付 2021年1月29日受理２021年3月8日J-STAGE早期公開 (Received on Dec. 21, 2020 ; Accepted on Jan. 29, 2021；J-STAGE Advance published on Mar. 8, 2021)

1）（株）神戸製鋼所技術開発本部材料研究所（Materials Research Laboratory, Technical Development Group, Kobe Steel, Ltd.)

2）（株）コベルコ科研材料ソリューション事業部 (Material Solutions Division, Kobelco Research Institute, Inc.)

* Corresponding author. E-mail: kawamori.makoto@kobelco.com, Address: Kobe Steel, Ltd., 1-5-5 Takatsukadai Nishi-ku Kobe Hyogo 651-2271 
$\mathrm{mm}$ の SCM 435 薄鋼板を用いた。鋼材 A は市販の鋼であ り，鋼材 $\mathrm{B}$ は真空誘導加熱炉で溶製した鋼である。900 $\mathrm{C}$, 15 分の焼入れ, $400{ }^{\circ} \mathrm{C}, 30$ 分の焼戻しを行い, 引張強度 $1500 \mathrm{MPa}$ 級の焼戻しマルテンサイト組織に調質した。

\section{$2 \cdot 2$ 大気暴露試験および陰極チャージ試験による水素添加}

鋼材 $\mathrm{B}$ から $70 \times 35 \times 1.6 \mathrm{~mm}$ の平板試験片を採取し, 大 気暴露試験に供した。また, 自動車用部材を想定した曲げ 加工となるU曲げ試験片も併せて大気暴露試験に供した。 U曲げ試験片の作製には，鋼材 A から $150 \times 30 \times 1.6 \mathrm{~mm}$ の 試験片を採取し，シャー切断によるせん断加工ひずみの影 響を排除するため試験片長辺端面をフライス加工した。こ の試験片を 3 点曲げによってU字形状に曲げ，曲げ半径は $10 \mathrm{~mm}$ とした。曲げの頭頂部に貼り付けたひずみゲージを 用いて計測されるひずみ量にヤング率を乗じた值を負荷応 力として, 試験片に通したボルトをナットで締め付けるこ とによって曲げ加工部に $1500 \mathrm{MPa}$ の応力を付与した。大 気暴露環境下での腐食による水素添加を目的として, 財団 法人日本ウェザリングテストセンター銚子暴露試験場 ${ }^{20)}$ にて大気暴露試験を行った。大気暴露試験の期間は, 平板 試験片に対しては2週間, U曲げ試験片に対しては3か月 とした。鋼中に侵入した水素の逃散を抑制するため, 大気 暴露試験後はドライアイスおよび液体窒素で試験片を冷却 した状態で保管した。大気暴露した試験片から水素分析用 試料を切り出した。切断時は水素逃散を防止するためにで きるだけ短時間で行い, 切断前後には液体窒素で試験片を 冷却した。

陰極チャージ試験による水素添加には $10 \times 10 \times 1.6 \mathrm{~mm}$ の試験片 (鋼材 $\mathrm{B})$ を用いた。ポテンショスタット／ガルバ ノスタットを用いて, 試験片に対し定電流制御により水素 添加を行った。ここで, 対極には白金を用い, チャージ溶 液には0.1 M NaOH水溶液を用いた。陰極チャージ試験は 約 $20^{\circ} \mathrm{C}$ で実施し, カソード電流密度およびチャージ時間は それぞれ $1 \mu \mathrm{A} / \mathrm{mm}^{2}, 48 \mathrm{~h}$ とした。

\section{$2 \cdot 3$ ブラスト処理}

ブラスト処理を用いて大気暴露試験で形成した錆の除去 を行った。ここでブラスト装置には, SNMアジア (株) 製 ハンディブラスターを用い，エアー源には圧縮空気あるい は圧縮乾燥空気を用いた。また，ブラスト処理の砥粒には 珪砂 (有) 竹折砄業所9号珪砂) あるいはアルミナ（サンゴ バン (株) 製 WHITE ABRAX F220）を使用した。珪砂は全 て同じ製品であるが，ロットによって水素分析結果が変化 したため, 珪砂 A, B, Cとロット毎に区別した。温度上昇 に伴う水素逃散を防止するために, ブラスト処理の前後は

Table 1. Chemical compositions of SCM 435 steels (mass\%).

\begin{tabular}{cccccccc}
\hline Steel & C & Si & Mn & P & S & Cr & Mo \\
\hline A & 0.35 & 0.29 & 0.69 & 0.008 & 0.004 & 0.97 & 0.18 \\
\hline B & 0.35 & 0.22 & 0.75 & 0.007 & - & 1.01 & 0.23 \\
\hline
\end{tabular}

液体窒素での冷却を行った。水素分析に及ぼすブラスト処 理の影響を調査するため, 暴露を行っていない試験片およ び陰極チャージ試験で水素添加を行った試験片に対して も, 同様のブラスト処理を行った。砥粒に用いた珪砂およ びアルミナの付着水分量は, $105^{\circ} \mathrm{C}$ での加熱気化カール フィッシャー法を用いて求めた。

\section{$2 \cdot 4$ 水素量測定および水素可視化}

水素量の測定には大気圧イオン化質量分析計 (Atmospheric Pressure Ionization Mass Spectrometer, API-MS）を用いた ${ }^{21) 。 ~}$ 水素脆化に影響すると考えられる拡散性水素量は一般的に $300^{\circ} \mathrm{C}$ までに放出される。そのため, 室温から $300^{\circ} \mathrm{C}$ まで昇 温したときに放出される水素の積算值を評価した。昇温速 度は $12^{\circ} \mathrm{C} \min ^{-1}$ とした。

水素の可視化には汎用セクター型SIMS を用いた。ここ で水素トラップサイトのトレーサーとして, 軽水素の代 わりに重水素を用いた。希少同位体である重水素をトレー サーとする同位体標識法により，鋼中に初期から存在する 軽水素と環境から侵入した重水素を分離して存在箇所を評 価することができる。さらに, 測定上のバックグラウンド 由来の水素と区別することが可能であるため, バックグラ ンド由来の水素を低減するための排気時間を短縮化するこ とができる。これにより, 試験片に含まれる水素が逃散す る前に, 水素可視化評価を開始することが可能である ${ }^{22)}$ 一次イオンビーム条件を $\mathrm{Cs}^{+}, 15 \mathrm{keV}$ とし, 走查イオン像 モードにて負の重水素イオン $\left({ }^{2} D^{-}\right)$を取得した。

\section{3. 結果}

\section{$3 \cdot 1$ 水素量測定に及ぼすブラスト処理の影響}

鋼中の水素分析に及ぼす錆の影響を把握するために, 大 気暴露試験後の試験片の錆が一部残るように, 意図的に $1 \mathrm{~s}$ 未満の短時間のブラスト処理を 3 回行い, 水素分析を行っ た結果を Fig.1に示す。ここでブラスト砥粒には珪砂 Aを 用いた。大気暴露試験で形成した錆はブラスト処理によつ て部分的に除去されているが，一部が残存していることが Fig.1（a）に示す外観写真からわかる。錆が残存した試験片 の水素量測定結果を Fig.1 (b) に示す。 $120^{\circ} \mathrm{C}$ 近傍をピーク とする低温側の水素放出に加え, $250^{\circ} \mathrm{C}$ 近傍をピークとす る高温側の水素放出が確認された。 $120^{\circ} \mathrm{C}$ 近傍をピークと する水素放出は拡散性水素であり, その一部は大気暴露試 験によって鋼中に侵入した水素由来である可能性が考えら れる。一方, $250^{\circ} \mathrm{C}$ 近傍をピークとする水素放出は錆由来と 推察される。Ishiguro らは錆の付いた鋼材を昇温脱離式力゙ スクロで分析を行った際の水素放出挙動を詳細に調査し, 錆と鉄との反応によって $300-400^{\circ} \mathrm{C}$ 高温域に水素が放出 されることを報告している ${ }^{19)}$ 。本実験においても同様に, 残存した錆と鋼が昇温脱離分析中に反応し, 高温側に水素 が放出されたことが考えられる。このような高温側の水素 
放出は低温側の水素放出にも裾を伸ばしており, 水素脆化 に影響すると考えられる低温側の鋼中の拡散性水素の定量 化を阻害する。すなわち, 錆は鋼中水素量の精密な測定に 対する阻害因子として働き，水素量測定前に十分に除去す る必要がある。そこで，次にブラスト処理による錆の除去 を検討した。

鋼の水素量測定に及ぼすブラスト処理の影響を調查す るために, 大気暴露後の試験片の錆が十分に除去されるよ う，長時間のブラスト処理を行った。ここで砥粒には珪砂 A を使用し，ブラスト時間の影響を調査するために, 1 回あ たりのブラスト時間を $1 \mathrm{~s}, 3 \mathrm{~s}, 10 \mathrm{~s}, 30 \mathrm{~s}$ としてブラスト回 数を変化させ，ブラスト処理の合計時間は $30 \mathrm{~s}$ で固定とし た。例えば 1 回あたりのブラスト時間を $1 \mathrm{~s}$ とする場合は, ブラスト処理を $1 \mathrm{~s}$ 行った後に液体窒素で冷却する作業を 試験片の表面と裏面に対してそれぞれ15回ずつ行い，合計 で30回のブラスト処理を実施して，ブラスト時間の合計は $30 \mathrm{~s}$ とした。得られた結果をFig.2に示す。大気暴露環境で の腐食によって形成した錆はブラスト処理によってほぼ完 全に除去されることがわかる (Fig.2 (a))。従って, 水素分 析に及ぼす錆の影響はほとんどないとして以下の議論を進 める。1回あたりのブラスト時間が長くなるにつれて, 水 素量が増加することが Fig.2 (b) からわかる。また, Fig.2 (c)
に示す水素放出曲線から，1回あたりのブラスト時間が長 くなるほど水素放出が増加するとともに, $300^{\circ} \mathrm{C}$ まで昇温 しても脱離しきらない高温側の水素放出が顕著になること が確認された。1回あたりのブラスト時間が長くなるほど， ブラスト処理に伴う発熱によって試験片温度が上昇し水素 量が減少することが当初予想されたが, 本結果は予想と反 対の傾向であった。実際にブラスト処理直後の試験片温度 を表面温度計で測定した結果，1回あたりのブラスト時間 が $1 \mathrm{~s}, 3 \mathrm{~s}, 10 \mathrm{~s}, 30 \mathrm{~s}$ と長くなるにつれて, $-22^{\circ} \mathrm{C},-19^{\circ} \mathrm{C}$ ， $-4^{\circ} \mathrm{C}, 25^{\circ} \mathrm{C}$ と表面温度が上昇することが確認された。大 気暴露試験での腐食によって鋼中に侵入した水素は, 試験 片温度の上昇によって逃散しやすくなると考えられるた め, 今回確認された 1 回あたりのブラスト時間の長期化に 伴う水素量の増加は, 大気暴露試験で侵入した鋼中水素で は説明できない。すなわち, ブラスト処理自体が水素量測 定に影響を及ぼしていると考えられる。

錆や腐食による水素の影響を排除し，ブラスト処理その ものが水素量測定に与える影響を調査するため, 大気暴露 試験を行わず腐食していない鋼に対してブラスト処理を 行った結果を Fig.3に示す。大気暴露後の試験片に対して ブラスト処理を行ったときと同様に, 1 回あたりのブラス 卜時間を $1 \mathrm{~s}, 3 \mathrm{~s}, 10 \mathrm{~s}, 30 \mathrm{~s}$ としてブラスト回数を変化させ， (a) Photographic images of specimen

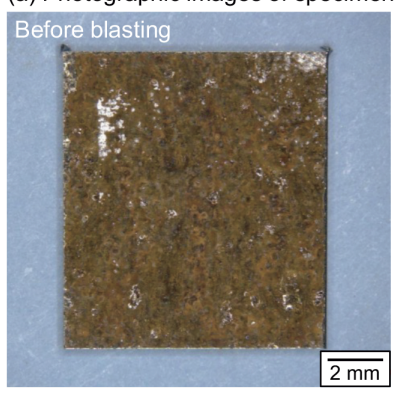

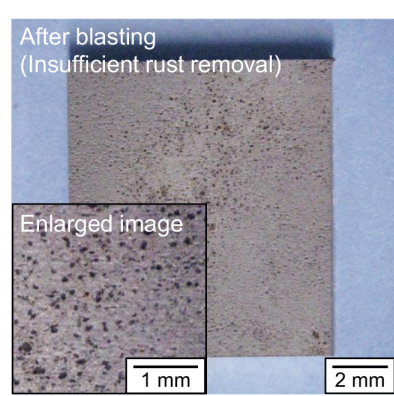

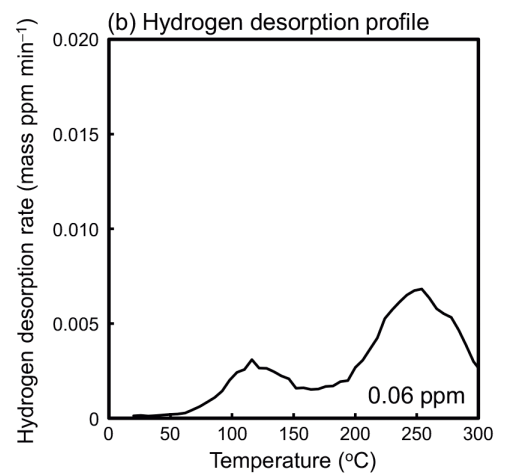

Fig. 1. (a) Photographic images of specimen before and after insufficient blasting using silica A to remove the rust formed by atmospheric corrosion. (b) Hydrogen desorption profile of specimen with residual rust after insufficient blasting. (Online version in color.)

(a) Photographic image

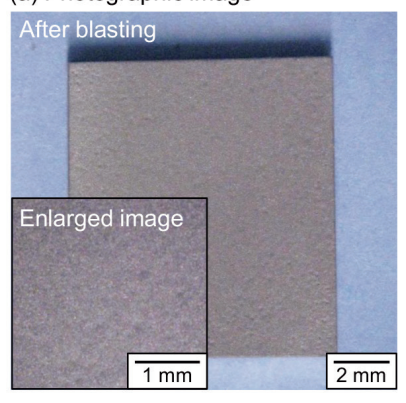

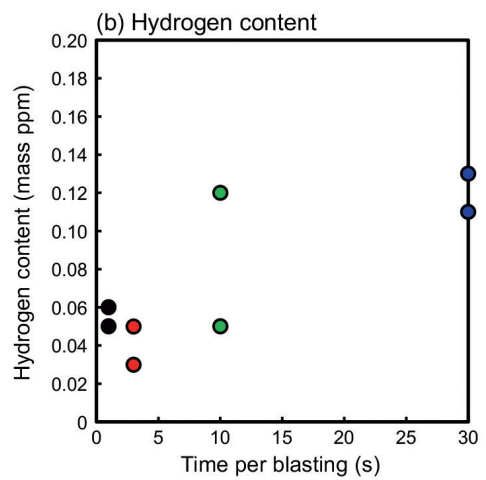

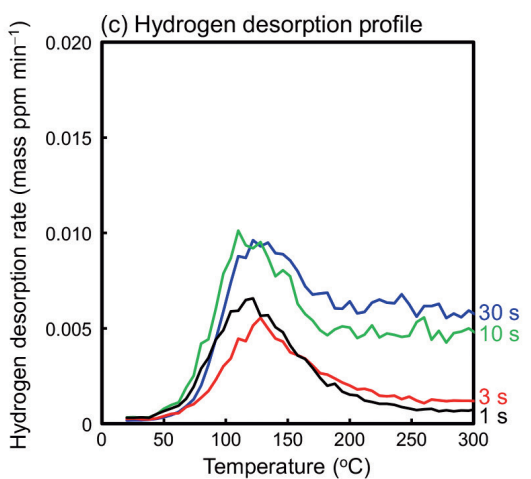

Fig. 2. (a) Photographic image of specimen after sufficient blasting using silica A to remove the rust formed by atmospheric corrosion. (b) Hydrogen contents and (c) hydrogen desorption profiles of corroded specimens after blasting when changing the time per blasting with the total time of blasting as 30 seconds. (Online version in color.) 
ブラスト処理の合計時間は $30 \mathrm{~s}$ で固定とした。砥粒には珪 砂 $\mathrm{A}, \mathrm{B}, \mathrm{C}$ を用いた。ブラスト処理を行わなかった試験片 の水素量は $0.01 \mathrm{ppm}$ 未満であり，ほとんど水素は含まれて いなかった。一方，ブラスト処理を行うことで水素量が増 加することが確認された。また，大気暴露した試験片を用 いた場合と同様に，1回あたりのブラスト時間が長いほど， 水素量が増加する傾向が確認された（Fig.3 (a))。珪砂 Bを 使用した場合の水素放出曲線を Fig.3（b）に示す。1回あた りのブラスト時間が長くなるにつれて，150 ${ }^{\circ} \mathrm{C}$ 近傍をピー クとする低温側の水素放出および $300^{\circ} \mathrm{C}$ でも低下しきらな い高温側の水素放出が確認された。特に, 珪砂 $\mathrm{B}$ を使用し た場合，最大で $0.18 \mathrm{ppm}$ もの水素量が検出されたが，これ は従来報告されている暴露試験での侵入水素量と比較して 無視できない高い值であることから，鋼中水素量を精密に 測定する目的において，ブラスト処理は阻害因子となりう ることが判明した。

水素分析に及ぼすブラスト処理の影響の試験片厚さ依 存性を調査した結果を Fig.4 に示す。本実験でのみ, 厚さが $6.0 \mathrm{~mm}$ の SCM 435 鋼板を供試材として用い, 板厚 $0.5 \mathrm{~mm}$ 〜 $5.8 \mathrm{~mm}$ の試験片 $(10 \times 10 \mathrm{~mm})$ を採取してブラスト処理 を行った。ブラスト処理には砥粒 Cを使用し，1回あたり のブラスト時間を $30 \mathrm{~s}$ （試験片の表面と裏面に対してそれ ぞれ $15 \mathrm{~s}$ ) としてブラスト回数は1回とした。試験片の板
厚が減少するにつれて水素量が増加する傾向が確認された (Fig.4 (a))。また, Fig.4 (b) に示す水素放出曲線から, 板 厚の減少とともに, $120^{\circ} \mathrm{C}$ 近傍をピークとする低温側の水 素放出および $300^{\circ} \mathrm{C} て ゙ も$ 低下しきらない高温側の水素放出 が増加することがわかる。板厚が大きい試験片では，ブラ ス卜処理によって鋼表面から近い領域には水素が侵入する ものの, 鋼表面から離れた領域では水素が十分拡散してお らず, 水素が少ない領域が占める割合が大きいため, 平均 の水素濃度としては少なく見積もられたと考えられる。一 方, 板厚が薄くなると比表面積が大きくなり，ブラスト処 理によって鋼表面から侵入した水素が存在する領域の占め る割合が大きくなるため, 平均水素濃度が高くなったと推 察される。特に薄鋼板や細径の線材などの比表面積が大き い試験片の錆を除去する場合において，ブラスト処理によ る水素量増加は注意すべき現象といえる。

\section{$3 \cdot 2$ ブラスト処理による水素量増加の水素源}

腐食に伴い鋼中に侵入した水素を精緻に評価するために は，阻害因子である錆を除去するとともに，ブラスト処理 による水素侵入の増加も抑制する必要がある。ブラスト処 理による水素量増加の抑制を目的として，ここではその原 因となる水素源の調査を行った。鋼への水素侵入機構の仮 説を Fig. 5 に示す。水素源となりうる水分が，ブラスト処理 によって露出した鋼新生面によって還元されて, 水素が発
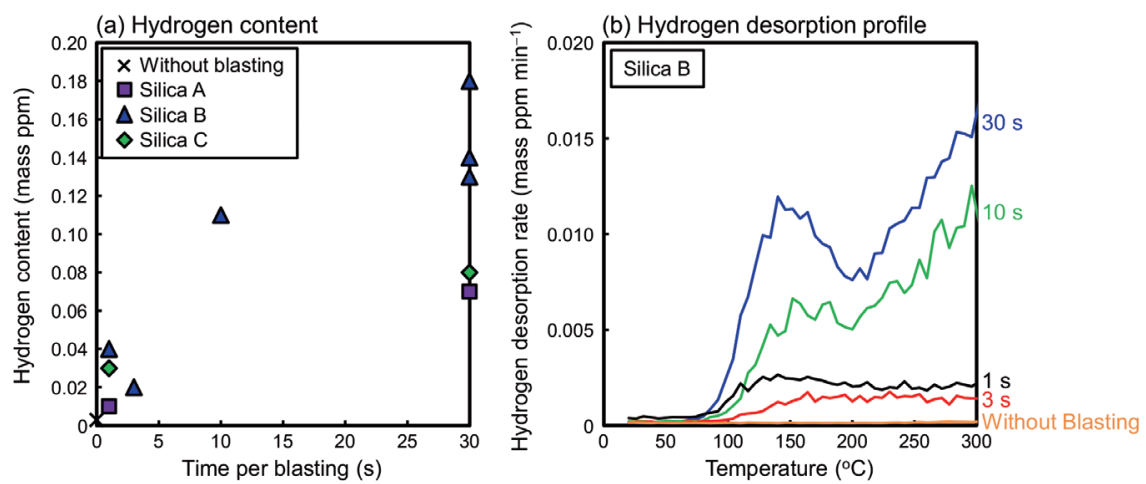

Fig. 3. (a) Hydrogen contents and (b) hydrogen desorption profiles of non-corroded specimens after blasting using silica A, B, C when changing the time per blasting with the total time of blasting as 30 seconds. (Online version in color.)
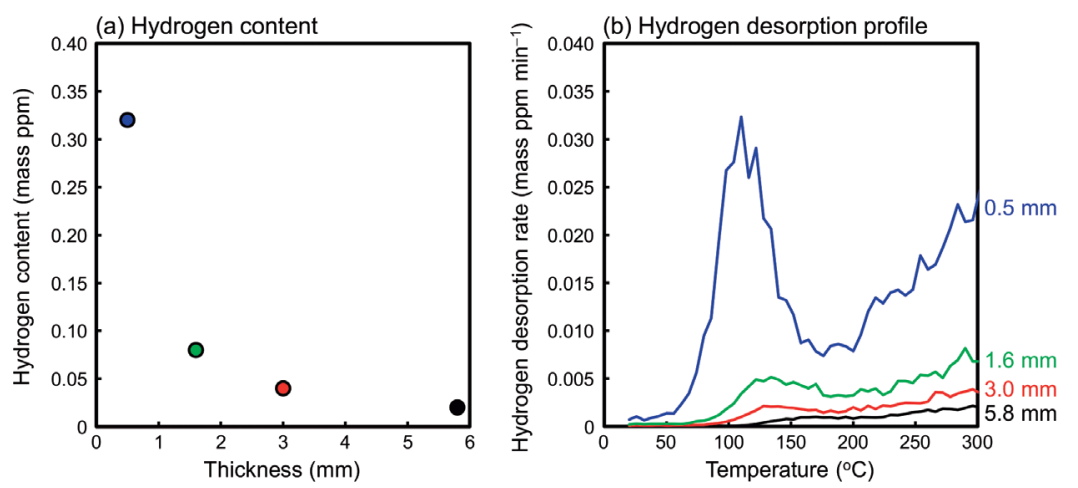

Fig. 4. (a) Hydrogen contents and (b) hydrogen desorption profiles of non-corroded specimens after blasting using silica $\mathrm{C}$ when changing the thickness of specimens. (Online version in color.) 
生すると伴に，その一部が鋼中に水素侵入するモデルを仮 定した。そして水素源としては，(i) 液体窒素から試験片を 取り出したときに試験片表面に付着する霜，(ii) ブラスト 処理に使用するエアー源に含まれる水分，(iii）砥粒に含ま れる水分，(iv）雰囲気中の水分，が考えられる。これら因 子の影響を以下に調査した。

\section{$3 \cdot 2 \cdot 1$ 霜の影響}

ブラスト処理前に試験片を液体窒素から取り出した際に 付着した霜がブラスト処理による水素量増加の水素源とな るか把握するため, 霜が付着した試験片と, 液体窒素から 取り出した後に室温に戻して霜を除去した試験片に対して ブラスト処理を行った。ここで, ブラスト処理には珪砂C を使用し，試験片の表面と裏面に対してそれぞれ $15 \mathrm{~s}$, 合 計 $30 \mathrm{~s}$ のブラスト処理を行った。霜が付着した試験片に対 してブラスト処理した場合の水素量は $0.08 \mathrm{ppm}$ であったの に対し, 霜を除去した場合は $0.09 \mathrm{ppm}$ と大きな差は確認さ れなかった。従って, 霜はブラスト処理による水素量増加 の水素源ではないとわかった。

\section{$3 \cdot 2 \cdot 2$ エアー源に含まれる水分の影響}

ブラスト処理のエアー源に含まれる水分の影響を調査す るために, エアー源に圧縮空気打よび圧縮乾燥空気を使用 したときの比較を行った。ブラスト処理には珪砂 $\mathrm{B} を($ 使用 し, 試験片の表面と裏面に対してそれぞれ $15 \mathrm{~s}$, 合計 $30 \mathrm{~s}$ のブラスト処理を行った。圧縮空気を用いた場合の水素量 は $0.13 \mathrm{ppm}$ であり, 圧縮乾燥空気を使用した場合の水素量 は $0.14 \mathrm{ppm}$ と同程度であったことから，エアー源に含まれ る水分はブラスト処理による水素量増加の水素源ではない と判断された。

\section{$3 \cdot 2 \cdot 3$ 砥粒に含まれる水分の影響}

ブラスト処理に使用した砥粒に含まれる水分の影響を調 查するために, 砥粒を乾燥させて水分を除去した場合の変 化を調査した。具体的には, 砥粒に使用した珪砂 Bを定温 乾燥器にて $200^{\circ} \mathrm{C} \times 24 \mathrm{~h}$ 以上の乾燥処理を行った。乾燥処 理後, 室温までの泠却に伴って大気中の水分が珪砂に再付 着することを抑制するために, 事前にモレキュラーシーブ で脱水したデシケータ内に乾燥後の珪砂とモレキュラー シーブを共に数時間保管して室温まで泠却した。珪砂に含

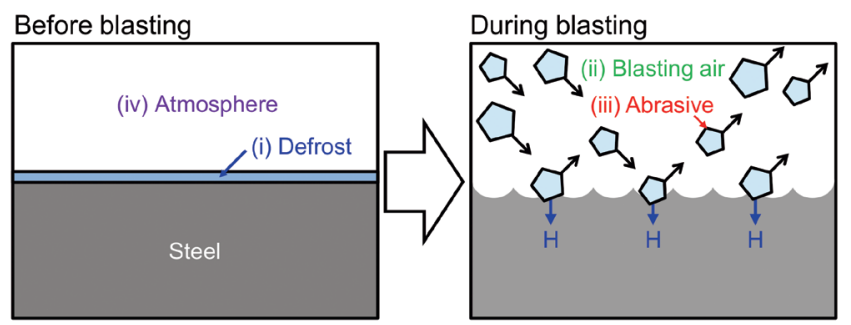

Fig. 5. Schematic illustration of (i)frost, (ii)blasting air, (iii) water in abrasive, and (iv) atmosphere, which are assumed as hydrogen sources for increasing the hydrogen content due to blasting. (Online version in color.)
まれる付着水分量は乾燥処理前に 0.12 mass\%であったの に対し，乾燥処理によって 0.07 mass\%まで低下すること がカールフィッシャー法によって確認された。乾燥させ た珪砂を用いて, 表面と裏面に対してそれぞれ $15 \mathrm{~s}$, 合計 $30 \mathrm{~s}$ のブラスト处理を行った試験片の昇温脱離分析結果を Fig.6 (a) に示す。乾燥処理を行わずブラスト処理した場合 は $0.14 \mathrm{ppm}$ の水素が検出されたのに対し, 乾燥处理を行っ た珪砂を用いた場合は $0.11 \mathrm{ppm}$ と水素放出が減少すること が確認された。乾燥処理による珪砂の付着水分量の低下に 伴い, ブラスト処理した鋼中の水素量の低下が確認された ことから, 砥粒に含まれる水分がブラスト処理による水素 量増加の水素源となることが間接的ではあるが示唆され た。砥粒に含まれる水分が水素源となることを直接的に証 明するために, 重水を付着させた珪砂を用いてブラスト処 理を行い, ブラスト处理後の試験片から重水素が検出され るか検証を行った。軽水 $\left(\mathrm{H}_{2} \mathrm{O}\right)$ と比較して, 重水 $\left(\mathrm{D}_{2} \mathrm{O}\right)$ は 自然界での存在比率が極めて低いため, 重水を付着させた 砥粒を用いたブラスト处理を行った試験片から重水素が検 出された場合には, 砥粒に含まれる水分が水素源だと断定 できる。実験方法としては, 事前にモレキュラーシーブで 脱水したデシケータ内に乾燥処理後の珪砂と重水を添加し たビーカーを共に数時間保管して室温まで泠却した。これ により, 乾燥処理で脱離させた軽水に代わって, ビーカー から蒸発した重水素が珪砂に吸着して置換すること(以 後, 重水置換处理と記載する) が可能である。重水を付着 させた珪砂を用いて, 試験片の表面と裏面に対してそれぞ れ $15 \mathrm{~s}$, 合計 $30 \mathrm{~s}$ のブラスト处理を行った。ブラスト処理 した試験片から放出された重水素の昇温脱離分析結果を Fig.6（b）に示す。重水置換処理を行わなかった場合は, 珪 砂の乾燥処理の有無によらず, ブラスト処理後の試験片か ら重水素はほとんど検出されなかった。一方, 乾燥处理後 に重水置換処理を行った珪砂を用いてブラス卜処理を行っ た試験片でのみ, 重水素が顕著に検出されることが明らか になった。本結果から，砥粒に含まれる水分が，ブラスト 処理による水素量増加の水素源となることが明確化された。
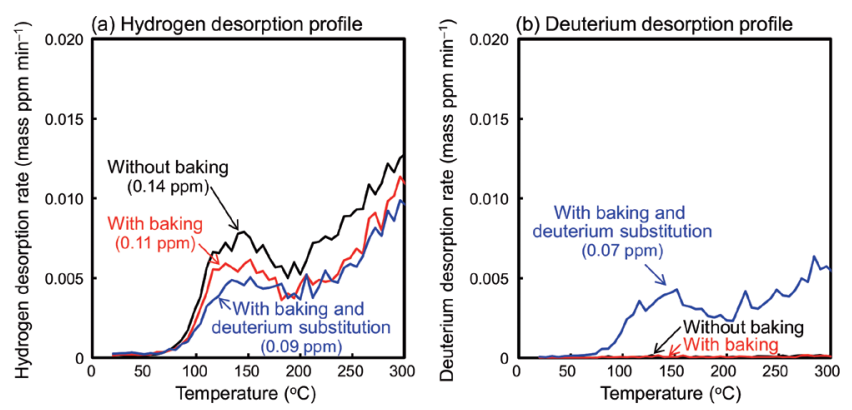

Fig. 6. (a) Hydrogen and (b) deuterium desorption profiles of non-corroded specimens after blasting using abrasive without baking, with baking, and with baking and deuterium substitution. Silica B was used as abrasive. (Online version in color.) 
Fig.6 (a) に示した軽水素の昇温脱離分析結果から, 重水置 換処理を行った場合に検出された軽水素は $0.09 \mathrm{ppm}$ であ り, 乾燥処理を行わなかった場合 $(0.14 \mathrm{ppm})$ や重水置換処 理を行わず乾燥させた珪砂を使用した場合 $(0.11 \mathrm{ppm})$ と比 較して, 低い值であることが確認された。これは, 乾燥処理 によって珪砂に含まれる軽水が脱離したことに加えて, 乾 燥処理後の室温までの冷却を重水䨌囲気中で行ったことで 砥粒に付着した重水によって軽水の再付着が抑制され, 珪 砂に含まれる軽水の量が減少したためだと考えられる。

\section{$3 \cdot 2 \cdot 4$ 䨌囲気中の水分の影響}

ブラスト処理における雰囲気中に含まれる水分の影響 を調査するために, 雲囲気を乾燥させて水分を除去した場 合の変化について調査した。䨌囲気中の水分量を制御する ために，ここでは簡易グローブボックス内でのブラスト処 理を実施した。砥粒には $3 \cdot 2 \cdot 3$ 項に記載した乾燥処理で 砥粒に含まれる水分を減らした珪砂 Cを使用し，モレキュ ラーシーブによって乾燥させたグローブボックス内（湿度 計で測定した相対湿度值 : $21 \% \mathrm{RH}$ ) でブラスト処理を行っ た試験片と，乾燥させなかったグローブボックス内（相対 湿度值：55\%RH）でブラスト処理を行った。ここで，ブラ スト時間は試験片の表面と裏面に対してそれぞれ $15 \mathrm{~s}$ ，合 計 $30 \mathrm{~s}$ とした。グローブボックス内を乾燥させずブラスト 処理した試験片の水素量は $0.06 \mathrm{ppm}$ であったのに対し, 乾 燥させた場合は $0.05 \mathrm{ppm}$ と水素量の低下が確認されたが, その差はわずかであった。したがって, 䨌囲気中の水分の 影響は少ないことがわかった。

上記結果から, ブラスト処理による水素量増加の水素源 は主に砥粒に含まれる水分であることが明らかになった。

\section{$3 \cdot 3$ ブラスト処理による水素量増加の抑制方法}

ブラスト処理による水素量増加の水素源が砥粒に含ま れる水分由来であることがわかったため, ブラスト処理に よる水素量増加の抑制を目的として，ここでは付着水分量 の少ない砥粒を用いたブラスト処理を検討した。具体的に は, 砥粒として珪砂に加えアルミナを使用してブラスト処 理を行った。珪砂 A, B, Cの水分量は 0.07, 0.12, 0.09 mass\% であり, 全て同じ製品名であるが付着水分量はロットに よって異なっていた。この原因は明らかではないが, 珪砂 の製造方法や製造時期あるいは保管方法によって, 付着水 分量が異なっていたと考えられる。アルミナの付着水分量 は 0.02 mass \%とであり, 珪砂と比較して少ないことが確認 された。これら砥粒を用いてブラスト処理を行った試験片 の水素量測定結果を Fig.7 (a) に示す。1回あたりのブラス ト時間を $1 \mathrm{~s}, 3 \mathrm{~s}, 10 \mathrm{~s}, 30 \mathrm{~s}$ としてブラスト回数を変化させ, ブラスト処理の合計時間は $30 \mathrm{~s}$ で固定とした。いずれの砥 粒でも，1回あたりのブラスト時間が短くなるにつれて， 水素量が低下する傾向が確認された。また, 砥粒にアルミ ナを使用した場合, 珪砂と比較して水素量が低下した。砥 粒に含まれる水分量とブラスト処理した試験片の水素量
との関係を Fig.7 (b) に示す。1回あたりのブラスト時間が $1 \mathrm{~s}, 30 \mathrm{~s}$ のいずれの場合も, 砥粒に含まれる水分量が多いほ ど, ブラスト処理後の水素量が増加することがわかる。本 結果もまた, 砥粒の付着水分量が水素源でありブラスト処 理での水素量増加の原因となることを示している。ブラス 卜処理による水素量増加を抑制するためには，1回あたり のブラスト時間を短時間化すると伴に, 付着水分量の少な い砥粒を使用することが有効である。

\section{4. 考察}

\section{$4 \cdot 1$ ブラスト処理による鋼への水素侵入の機構}

ブラスト処理による鋼への水素侵入の仮説として, Fig.5 に示すように, 水素源となる水分（特に砥粒に含まれる水 分）が，ブラスト処理によって露出した鋼新生面によって 還元されて水素発生すると伴に, その一部が鋼中に水素侵 入するモデルを仮定した。ここでは水素放出プロファイル の解析やSIMS による水素可視化手法を用いて，ブラスト 処理による鋼への水素侵入機構の詳細を考察する。ブラス 卜処理後の試験片の水素放出プロファイルは, $100 \sim 200^{\circ} \mathrm{C}$

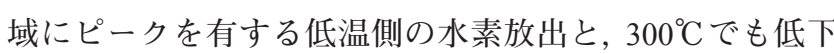
しきらない高温側の水素放出の2 種類の水素放出から構成 される (Fig.3)。これら水素が鋼中に侵入した拡散性水素 かあるいは非拡散性水素か, 水素存在状態を明らかにする ために，ブラスト処理後に一定期間の室温放置を行った 後, 水素量測定を行った結果を Fig.8 に示す。ブラスト処理 後すぐに液体窒素に保管し, 水素量測定を行った場合は, $0.18 \mathrm{ppm}$ の水素量が検出された。一方, ブラスト処理後に 室温で放置して液体窒素保管を行った試験片の水素量は, 1 日の放置で $0.11 \mathrm{ppm}$ に低下し，1日以降 10 日の放置まで は水素量がほぼ一定となった。Fig.8 (b) に示す水素放出プ ロファイルから，100〜 $200^{\circ} \mathrm{C}$ 域にピークを有する低温側の 水素放出が, 室温での放置によって消失し, これは拡散性

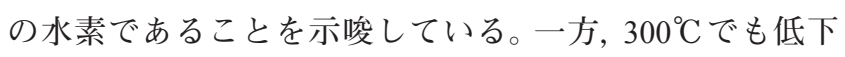
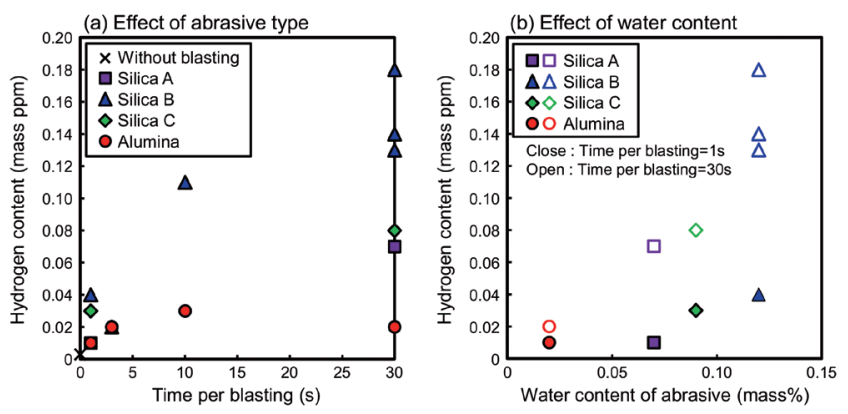

Fig. 7. (a) Relationship between hydrogen contents of noncorroded specimens after blasting and time per blasting when changing the abrasives. (b) Relationship between hydrogen contents of non-corroded specimen after blasting and water contents of abrasives. (Online version in color.) 
しきらない高温側の水素放出は, 室温での放置時間に関わ らず残存しており，非拡散性の水素であることがわかる。 一般的に，腐食や陰極チャージなどで水素を添加した場合 は，拡散性水素として鋼中に存在し，室温放置で逃散する。 ブラスト処理した試験片の水素量測定で確認された 100 $200^{\circ} \mathrm{C}$ 域ピークの低温側の水素放出も室温放置で逃散する ことから，鋼中に侵入した拡散性水素であると考えられる。

ブラスト処理によって鋼中に水素が侵入することを直 接的に証明するために, SIMSを用いて鋼断面の水素可視 化を行った。具体的には, $3 \cdot 2 \cdot 3$ 項で実施したのと同様 に, 乾燥処理後に重水置換した砥粒を用いてブラスト処理 を行った試験片の断面における重水素を可視化した結果 をFig.9に示す。Fig.9 (c) で ${ }^{72} \mathrm{FeO}^{-}$が強く検出される領域 が鋼の断面部分であるが，鋼内部に重水素 $\left({ }^{2} \mathrm{D}^{-}\right)$が存在す ることがFig.9 (a) からわかる。本結果は，砥粒に含まれる 水分由来の水素が鋼中に侵入することを明確に示すもので ある。鋼内部だけでなく, 鋼表面にも重水素が存在するこ とがわかる。鋼表面の重水素の存在位置と, 砥粒由来のケ イ素 $\left({ }^{28} \mathrm{Si}^{-}\right)$の存在位置は一致していた。検出されたケイ 素は，ブラスト処理後に鋼表面に残存した珪砂の可能性が 考えられたことから，ブラスト処理前後での試験片の断面 SEM 観察とEDX分析を行った結果を Fig.10に示す。ここ で，1回あたりのブラスト時間を $1 \mathrm{~s}, 30 \mathrm{~s}$ としてブラスト回 数を変化させ，ブラスト処理の合計時間は $30 \mathrm{~s}$ で固定とし た。ブラスト処理前 (Fig.10 (a)) には確認されなかった Si,
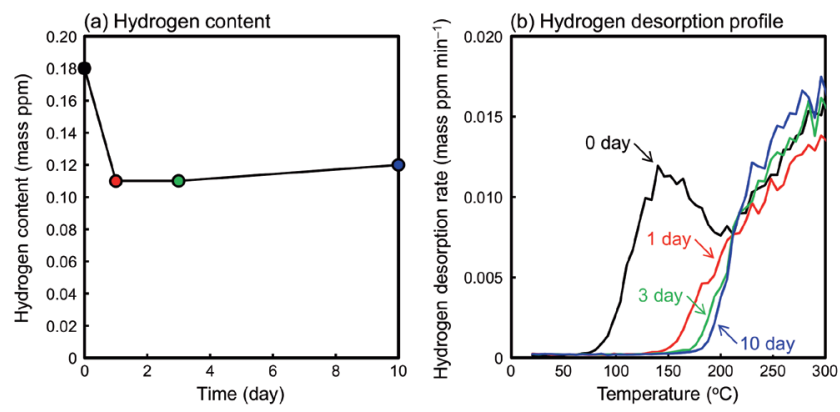

Fig. 8. Time dependence of (a) hydrogen contents and (b) hydrogen desorption profiles of non-corroded specimens kept at room temperature after blasting. Silica B was used as abrasive. (Online version in color.)
Oがブラスト処理後の試験片表面には確認され, これは鋼 表面に珪砂が残存することを示している。従って, SIMSで 確認された鋼表面の重水素は, 残存した珪砂に含まれる重 水由来と推察される。1回あたりのブラスト時間が $1 \mathrm{~s}$ のと き (Fig.10 (b) ) と比較して $30 \mathrm{~s}$ と長いほど (Fig.10 (c)), 鋼 表面に残存する珪砂の量が多くなることがわかる。以上の ようにSIMSによる水素可視化から, 鋼中に存在する水素 と鋼表面に残存する砥粒に含まれる水分由来の水素の2種 類の水素存在状態が確認された。これと水素放出プロファ イルで見られた $100 \sim 200^{\circ} \mathrm{C}$ 域の低温側の水素放出と $300^{\circ} \mathrm{C}$ でも低下しきらない高温側の水素放出の 2 種類の水素放出 との対応と考えると, 鋼中に侵入した拡散性水素が 100〜 $200^{\circ} \mathrm{C}$ 域の低温側の水素放出であり，鋼表面の砥粒に含ま れる水分が昇温脱離分析中に鋼と反応して生じた水素が高 温側の水素放出の原因であることが推察される。鋼表面に 残存した砥粒に含まれる水分は室温で安定であることか ら，ブラスト処理後に室温放置を行った試験片においても 変わらず，高温側に水素放出が確認されたと説明できる。

上記結果を踏まえ, ブラスト処理による鋼への水素侵入 の機構の模式困をFig.11に示す。ブラスト処理によって露 出した活性な鋼新生面によって, 砥粒に含まれる水分が還 元されて水素発生し, その一部が拡散性水素として鋼中 に侵入する (Fig.11 (b))。ブラスト処理後, 鋼中には拡散 性水素が存在し，鋼表面には水分を含む砥粒が残存する (Fig.11 (c))。これに対し昇温脱離分析を行うと, 鋼中の拡 散性水素は $100 \sim 200^{\circ} \mathrm{C}$ 域の低温側にピークを持って放出 される。さらに高い温度まで昇温を行うと, 鋼表面の砥粒 に含まれる水分と鋼とが反応し $\left(\mathrm{Fe}+\mathrm{H}_{2} \mathrm{O} \rightarrow\right.$ Ferrioxide +

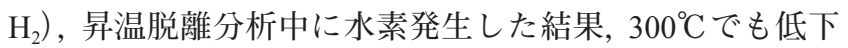
しきらない高温側の水素放出として検出されたと考えられ る(Fig.11 (d))。

\section{$4 \cdot 2$ ブラスト処理による鋼への水素侵入の抑制機構}

ブラスト処理による鋼の水素量増加の抑制には, 1 回あ たりのブラスト時間を短くすることと，付着水分量が少 ない砥粒を使用することが有効であることを Fig.7に示し た。ここでは，その抑制機構について考察を行う。1回あた りのブラスト時間が短いほど水素侵入が抑制される機構 (a) ${ }^{2} D^{-}$ion image

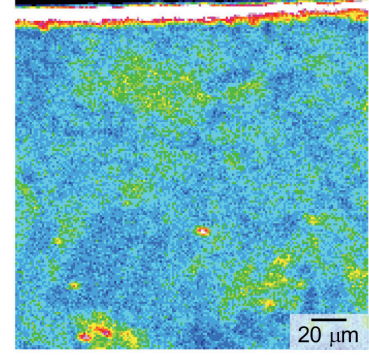

(b) ${ }^{28} \mathrm{Si}^{-}$ion image

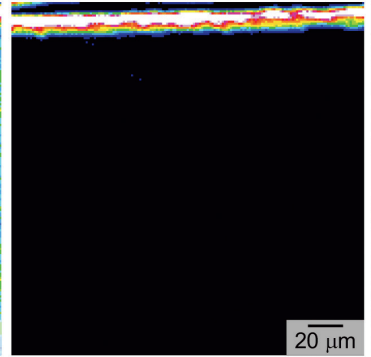

(c) ${ }^{72} \mathrm{FeO}^{-}$ion image

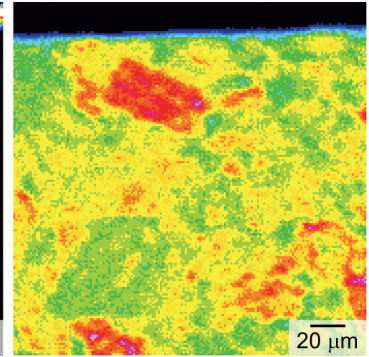

Fig. 9. SIMS images of (a) ${ }^{2} \mathrm{D}^{-}$, (b) ${ }^{28} \mathrm{Si}^{-}$, and (c) ${ }^{72} \mathrm{FeO}^{-}$in specimen after blasting using abrasive with baking and deuterium substitution. Silica B was used as abrasive. (Online version in color.) 
は，ブラスト処理による発熱での鋼の温度上昇が抑えられ ることと, 鋼表面に残存する砥粒が少なくなることが原因 と考元られる。すなわち, 一般的に鋼と水分との酸化還元 反応 (腐食反応) は温度が高いほど促進されるため, 1 回あ たりのブラスト時間が長い場合は, 温度上昇によって鋼と 砥粒の付着水分との腐食反応および水素発生反応が活発 になり，水素が侵入しやすくなる。一方，1回あたりのブラ スト時間が短く, 鋼の温度が低い場合には，腐食反応およ び水素発生・侵入反応が抑制されたと推察される。また, Fig.10に示したように 1 回あたりのブラスト時間が短いほ ど，鋼表面に残存する砥粒が少なる。これは 1 回あたりの ブラスト時間が長いほどエアー圧力が安定し，砥粒が鋼に 衝突する圧力が強くなったためだと推察される。水素放出 プロファイルで $300{ }^{\circ} \mathrm{C}$ でも放出しきらない高温側の水素放 出は，砥粒に含まれる水分と鋼との反応で生じたと仮定す ると, 1 回あたりのブラスト時間が短いほど, 鋼表面に残 存する砥粒が減少した結果, 高温側の水素放出が低下した と考えられる。

砥粒の付着水分量が少ないほど水素量増加が抑制された 機構は, 水素放出プロファイルにおける低温側および高温 側の水素放出の原因が砥粒に含まれる水分であるためと理 解できる。すなわち, 砥粒の付着水分量が少ないほど, 鋼 新生面との反応で発生して鋼中に侵入する水素が低減し, 低温側の拡散性水素量が低下する。また，ブラスト处理後 に鋼表面に残存した砥粒中の水分量が少なくなるため, 昇 温脱離分析中に鋼との反応で生じる高温側の水素放出も低 減したと考えられる。

\section{$4 \cdot 3$ 鋼中水素量を正しく評価するためのブラスト処理}

ブラスト処理による水素量増加を抑制する方法を検討し たが，ブラスト処理中の発熱等によって鋼中の水素が逃散 してしまう可能性も考えられる。そこで, 本ブラスト処理 が鋼中水素量の逃散を促すことがないか調査を行った。具 体的には, 予め陰極チャージで水素添加を行った試験片に 対しブラスト処理を行い，水素分析に供した。ブラスト処 理が不適切な比較例として砥粒に水分量の多い珪砂 B 用い，1回あたりのブラスト時間を $30 \mathrm{~s}$ として試験片の表 面と董面に対してそれぞれ15 s のブラスト処理を行った結

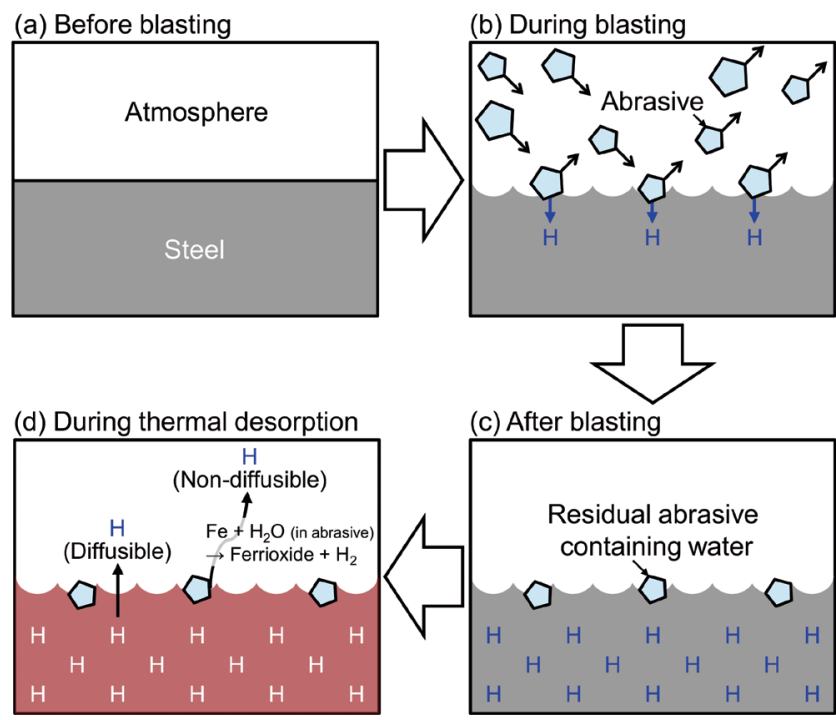

Fig. 11. Schematic illustration of hydrogen entry mechanism into steel by blasting. (Online version in color.)

\section{(a) Without blasting}
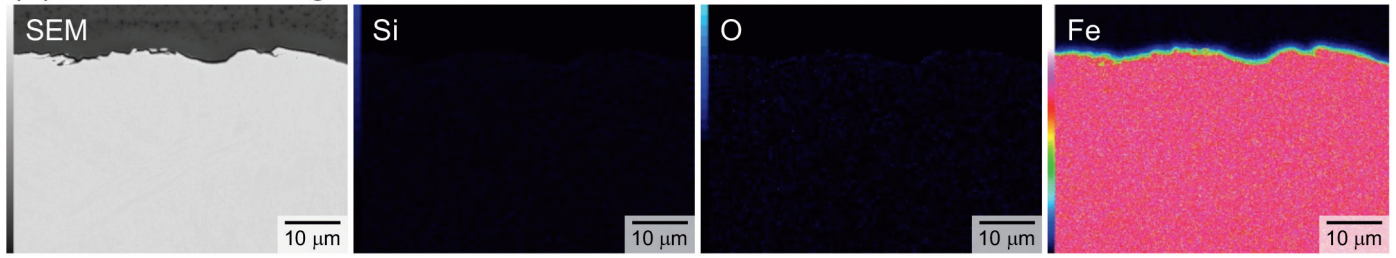

(b) With blasting (Silica, time per blast : 1s)
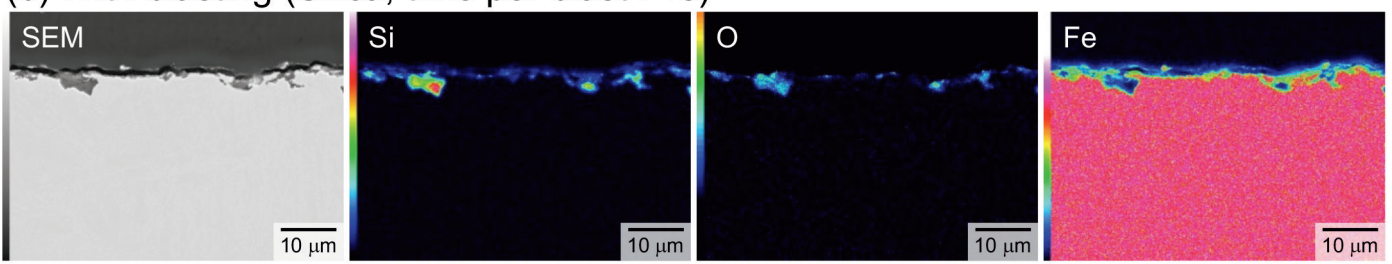

(c) With blasting (Silica, time per blast : 30s)
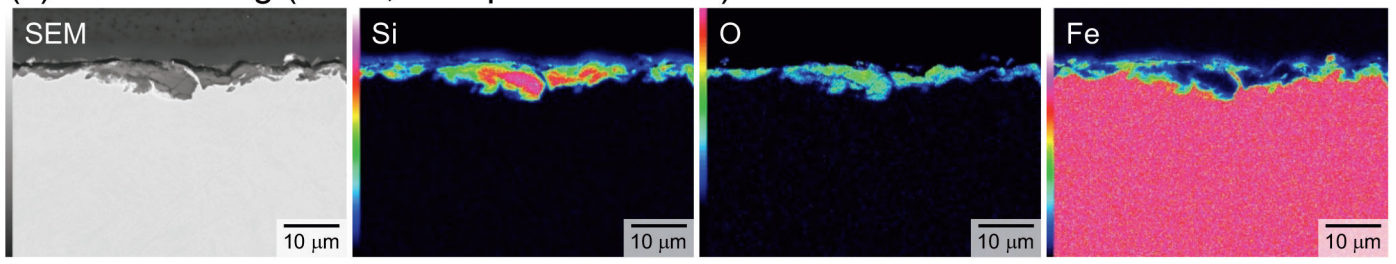

Fig. 10. SEM and EDX mapping images of specimens (a) before blasting, (b) after blasting with $1 \mathrm{~s}$ time per blasting, and (c) after blasting with $30 \mathrm{~s}$ time per blasting. Silica B was used as abrasive. (Online version in color.) 
果をFig.12（a）に示す。ブラスト処理を行わず陰極チャー ジを行った場合は, $100 〜 200^{\circ} \mathrm{C}$ 域の低温側にピークを持つ 拡散性水素 (0.04 ppm) の放出が確認された。一方, 陰極 チャージ後に珪砂を用いてブラスト処理を行った場合は, $100 \sim 200^{\circ} \mathrm{C}$ 域の低温側の水素放出打よび $300^{\circ} \mathrm{C}$ まで放出し きらない高温側の水素放出が増加し, 水素量は $0.20 \mathrm{ppm} に$ 増加した。水素チャージを行わずブラスト処理のみを行っ た場合の水素放出プロファイルを同時に示すが，ブラスト 処理によって $0.14 \mathrm{ppm} の$ 水素量増加が確認される。陰極 チャージで鋼中に侵入した水素にブラスト処理による水 素侵入が重畳された結果, ブラスト処理前の $0.04 \mathrm{ppm}$ から $0.20 \mathrm{ppm}$ まで水素量が増加したと考えられる。また, 珪砂 を用いて 1 回あたりのブラスト時間を $1 \mathrm{~s}$ とてて試験片の 表面と裏面に対してそれぞれ 15 回の合計 $30 \mathrm{~s}$ のブラスト 処理を行った結果を Fig.12（b）に示す。1回あたりのブラ スト時間を $30 \mathrm{~s}$ から $1 \mathrm{~s}$ に短時間化することにより，ブラ ス卜处理による水素量増加が 0.14 ppmから 0.04 ppmに減 少し, 陰極チャージ後にブラスト処理した場合の水素量も $0.20 \mathrm{ppm}$ から $0.10 \mathrm{ppm}$ に低下寸る。しかしながら, 珪砂の ような付着水分量が高い砥粒を用いた場合は, 1 回あたり のブラスト時間を短時間化した場合でもブラスト処理での 水素侵入によって, 鋼中水素量を正しく測定できないこと がわかる。それに対し，砥粒に付着水分量の少ないアルミ

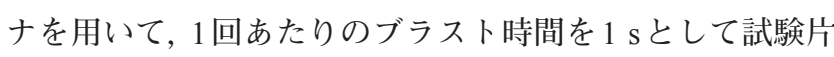
の表面と裏面に対してそれぞれ 15 回の合計 $30 \mathrm{~s}$ のブラス 卜处理を行った結果を Fig.12 (c) に示す。陰極チャージで の水素添加を行わず, ブラスト处理のみを行った試験片の 水素量は $0.01 \mathrm{ppm}$ であり, ブラスト処理による水素増加は わずかであった。また，陰極チャージで水素添加した試験 片の水素量拉よび水素放出プロファイルはブラスト処理前 後で大きな変化がないことが確認された。すなわち，本条 件ではブラスト処理中の水素侵入打よび水素逃散のいずれ も抑制できて抢り，鋼中水素量の測定を阻害しないことが わかった。
最後に，腐食した鋼（U曲げ試験片）の錆を異なるブラ スト方法で除去した場合の水素量測定結果を比較する。大 気暴露試験後のU曲げ試験片の頭頂部から2つの水素分析 用試験片を切断して採取し, ブラスト方法を変化させて錆 除去を行った。水素分析用の錆除去が不適切な比較例とし て, 砥粒に珪砂 Bを用いて 1 回あたりのブラスト時間を 30 sとして脱錆した場合の水素分析結果を Fig.13（a）に示す。 適切な例として，アルミナを用いて1回あたりのブラスト 時間を $1 \mathrm{~s}$ とした場合の水素分析結果を Fig.13（b）に示す。 大気暴露後のU曲げ試験片と, U曲げ試験片から切り出し てブラスト処理を行った水素分析用試験片の外観写真を併 せて示すが, ブラスト処理後は錆の残存は確認されなかっ た。砥粒に珪砂を用いた場合の水素量は $0.23 \mathrm{ppm}$ であった が，これは併せて示す腐食していない試験片にブラスト処 理を行った場合の水素量増加 $(0.18 \mathrm{ppm})$ が暴露試験で侵 入した水素量に畳重された結果である。これに対し, 砥粒 にアルミナを用いた場合の水素量は $0.05 \mathrm{ppm}$ であり, 繰り 返しになるが本条件ではブラスト処理による水素量増加や 水素逃散がほとんど起きないことが確認できているため, 本值が腐食で侵入した本来の鋼中水素量であると考えられ る。200ををピークとする水素放出は, 曲げを行わなかった 場合の $100 \sim 200^{\circ} \mathrm{C}$ 域の水素放出 (Fig. 12) と比較して, 高温 側にピークシフトしている。これはU曲げによって導入さ れた転位, 空孔などの格子久陥によってより安定な高温側 に水素トラップされたことと, 水素の拡散速度が低下して 昇温脱離試験中の水素放出が遅れたことが原因と考えられ る。砥粒に珪砂とアルミナを用いた場合とでブラスト処理 後の外観は同じような仕上がりであるが, 水素量は大きく 異なり, 錆除去のためのブラスト方法がいかにその後の水 素量測定結果に影響するかがわかる。このように, 腐食し た試験片の錆を除去する際にブラスト方法が不適切である 場合は, ブラスト処理に伴う水素量増加によって, 本来よ り過大に環境から入る水素量を評価してしまう。環境から 入る水素量を過大に評価してしまうと, 場合によっては使
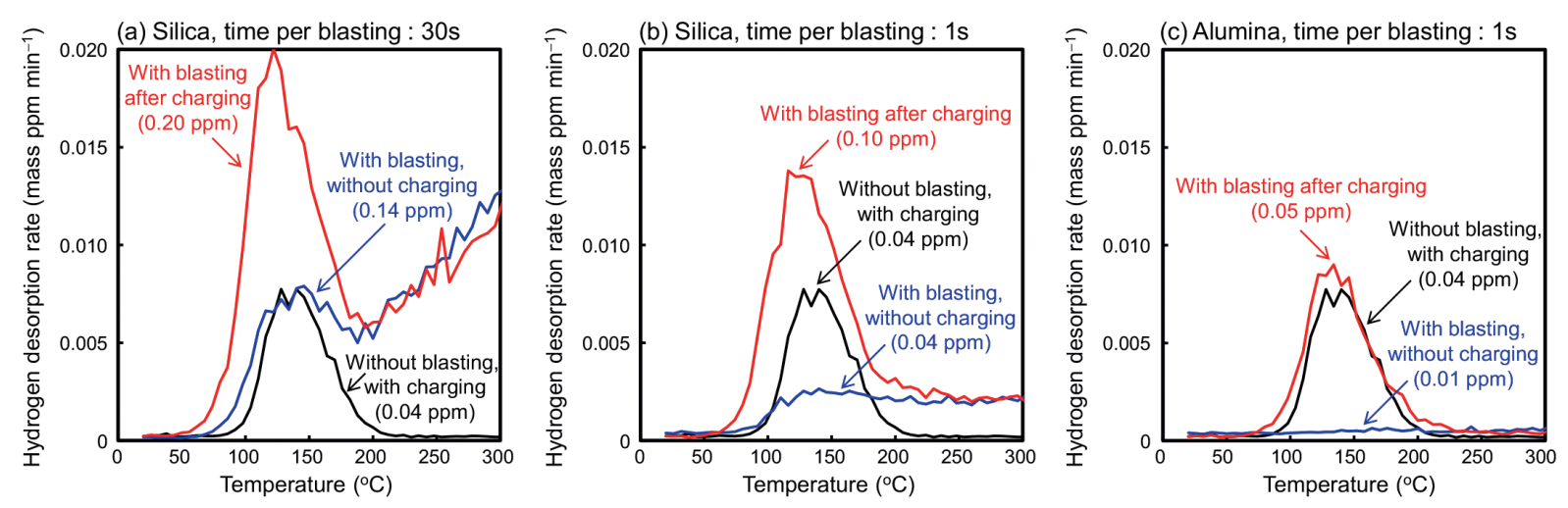

Fig. 12. Hydrogen contents and hydrogen desorption profiles of non-corroded specimens with blasting, without blasting after charging, and with blasting after charging. (a) Silica B was used as abrasive with $30 \mathrm{~s}$ time per blasting. (b) Silica B was used as abrasive with $1 \mathrm{~s}$ time per blasting. (c) Alumina was used as abrasive with $1 \mathrm{~s}$ time per blasting. (Online version in color.) 

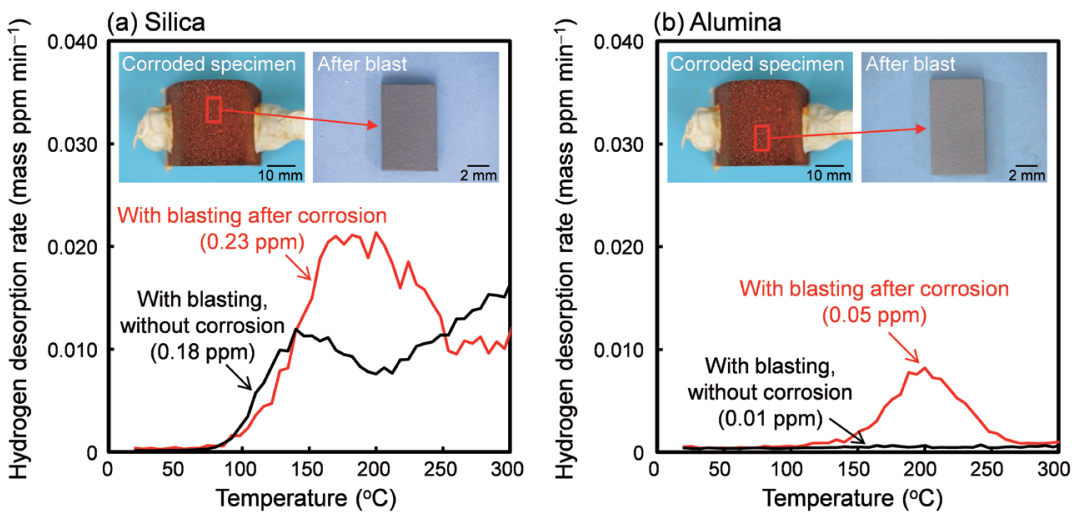

Fig. 13. Hydrogen contents and hydrogen desorption profiles of the corroded $\mathrm{U}$ bend specimen after blasting and the non-corroded specimen after blasting. (a) Silica B and (b) alumina were used as abrasives. (Online version in color.)

用環境を実態より過酷なものとして高強度鋼の適用可否を 見誤ってしまう問題がある。本研究は, 腐食した鋼の水素 量を精緻に測定するための水素量測定方法を提供するもの でり，今後さらなる発展が予想される高強度鋼の水素脆化 研究に活用されることを期待している。

\section{5. 結言}

本研究では, 腐食環境で鋼に侵入した水素を正しく評価 するための水素分析方法の確立を目的として, 錆を除去す るためのブラスト処理が水素量測定に及ぼす影響について 調査した。その結果, 以下の知見が得られた。

（1）ブラスト処理によって鋼に水素侵入することが確認さ れた。その効果は比表面積が大きい試験片の場合に顕 著であり, 鋼中水素量の測定における阻害因子となる ことに注意が必要である。

（2）ブラスト処理による水素量増加の水素源は主に砥粒に 含まれる水分である。

（3）ブラスト処理による鋼の水素量増加の機構は，ブラス 卜処理で露出した活性な鋼の新生面と砥粒に含まれる 水分とが反応して水素発生・侵入したことと, 鋼表面 に残存した砥粒の水分と鋼とが昇温脱離分析中に反応 し，水素放出されたことによると考えられる。

（4）ブラスト処理での水素侵入の抑制には，水分量の少な い砥粒を使用し，ブラスト処理による発熱を抑制する ために 1 回あたりのブラスト時間を短く繰り返して錆 除去することが有効である。

\section{謝辞}

この成果は, 国立研究開発法人新エネルギー・産業技術 総合開発機構 (NEDO) の委託業務の結果得られたもので す。ここに感謝申し上げます。

\section{文献}

1 ) S.Matsuyama: Delayed Fracture, Nikkan Kogyo Shimbun, Tokyo, (1989), (in Japanese).

2 ) M.Nagumo: Fundamentals of Hydrogen Embrittlement, Uchida Rokakuho Publishing, Tokyo, (2008), (in Japanese).

3 ) S.Matsuyama: Tetsu-to-Hagané, 80(1994), 679 (in Japanese).

4 ) T.Kushida, H.Matsumoto, N.Kuratomi, T.Tsumura, F.Nakazato and T.Kudo: Tetsu-to-Hagané, 82(1996), 297 (in Japanese).

5 ) Y.Namimura, N.Ibaraki, T.Hasegawa and Y.Oki: Kobe Steel Eng. Rep., 52(2002), No. 1, 25 (in Japanese).

6 ) T.Manabe and Y.Miyakoshi: Nippon Steel Tech. Rep., 412(2019), 122 (in Japanese).

7 ) Guidebook for Evaluation of Delayed Fracture Property of High Strength Bolts, JSSC Technical Report 91, Japanese Society of Steel Construction, Tokyo, (2010), (in Japanese).

8 ) J.Kinugasa, F.Yuse, M.Tsunezawa and M.Nakaya: ISIJ Int., 56(2016), 459.

9 ) N.Suzuki, N.Ishii, T.Miyagawa and H.Harada: Tetsu-to-Hagané, 79(1993), 227 (in Japanese).

10) S.Yamasaki and T.Takahashi: Tetsu-to-Hagané, 83(1997), 454 (in Japanese).

11) T.Omura, T.Kushida, F.Nakasato, S.Watanabe and I.Oyamada: Tetsuto-Hagané, 91(2005), 478 (in Japanese).

12) Y.Toji, S.Takagi, M.Yoshino, K.Hasegawa and Y.Tanaka: Tetsu-toHagané, 95(2009), 887 (in Japanese).

13) J.Kinugasa, F.Yuse, M.Tsunezawa and Y.Mukai: Kobe Steel Eng. Rep., 61(2011), No. 2, 65 (in Japanese).

14) M.Nagumo and K.Takai: Bull. Iron Steel Inst. Jpn., 22(2017), 442 (in Japanese).

15) S.Sakashita, E.Akiyama, K.Tsuzaki and S.Matsuyama: Tetsu-toHagané, 88(2002), 849 (in Japanese).

16) T.Kushida: ISIJ Int., 43(2003), 470.

17) N.Uno, M.Kubota, M.Nagata, T.Tarui, H.Kanisawa, S.Yamasaki, K.Azuma and T.Miyagawa: Nippon Steel Tech. Rep., 387(2007), 85 (in Japanese).

18) S.Li, E.Akiyama, N.Uno, K.Hirai, K.Tsuzaki and B.Zhang: Corros. Sci., 52(2010), 3198.

19) Y.Ishiguro, K.Fujimura, S.Ootsuka and A.Kobayashi: Trans. Jpn. Soc. Spring Eng., 63(2018), 27 (in Japanese)

20) Handbook of Outdoor Exposure Testing, Japan Weathering Test Center, Tokyo, (2007) (in Japanese).

21) T.Iwata: Koberunikusu, 47(2017), 17 (in Japanese).

22) M.Kawamori, W.Urushihara and S.Yabu: ISIJ Int., 61(2021), (Advance Publication). https://doi.org/10.2355/isijinternational.ISIJINT-2020-463 